\title{
Between the Americas and Europe: Mapping Territories through Questionnaires, 16th-18th Centuries
}

\author{
Simona Boscani Leoni
}

In the last decades, the Internet and electronic media have revolutionized our capacity to acquire and disseminate knowledge. These circumstances have drawn scholarly attention to the origins, development, and consequences of new information and communication technologies and to the problem of the collection of data and information over the centuries. As Paul Slack writes in a study about government and information in 17th-century England: "Studies of the information revolution brought about by modern electronic media have naturally prompted interest in how information was created, diffused and manipulated in the past and with what effects." The focus in this respect has very much been on the early-modern period in Europe in which developments such as the creation of a market for printed matter and the expanding bureaucracy of both State and Church contributed to a huge elaboration of ways in which ideas, information, and instructions were communicated and received.

Precisely at this time, queries and questionnaires first made their debut as a research tool - a tool so beloved today of government agencies, political analysts or market researchers - for data collection used by natural historians, antiquarians, and geographers, as well as by governments and public officials ("Beamte").

In speaking about queries and questionnaires in the early modern age, it is worth considering their genesis as a result of different processes. First, the process of state building and empire building and the need, for several countries, to extend their political, economic and commercial control on their colonies and to improve knowledge of natural resources, which could be exploited. On the one hand, the Spanish Cuestionarios para la formación de las Relaciones geográficas de Indias, and on the other hand pastoral visitations organized by bishops are similar instruments designed to achieve better administrative

1 Paul Slack, "Government and Information in Seventeenth-Century England," Past and Present 184 (2004): 33 . 
communication between centres (of the Spanish Empire or of a diocese) and their peripheries. We may even say that the origin of the European bureaucracy was strongly influenced by the Church, an institution very concerned with the retrieval of information from official registers. Royal chanceries were slower than the papacy in developing techniques for administration. After the Council of Trent (1545-1563), each parish priest of the Catholic Church was required to record births, deaths and marriages in registers. At the same time, Pastoral visits became regular good practice for bishops wanting to control the spiritual life of parishioners. ${ }^{2}$ For ecclesiastical and secular rulers an improved knowledge in geography, natural sciences, and anthropology of a region through a systematic collection of information - underpinned a more effective organization and centralization of their power. ${ }^{3}$ Secondly, there was an intensification of contacts between the Old and the New World through travels and a growing flow of data and information. Travels and travel narratives were often the only way to gather information about yet unknown and littleexplored territories: "travel across the globe was a major means for extending

2 Peter Burke, A Social History of Knowledge: From Gutenberg to Diderot (Cambridge: Blackwell Publishers, 2000), 120-23; Burke, The Historical Anthropology of Early Modern Italy: Essays on Perception and Communication (Cambridge: Cambridge University Press, 1987).

3 About pastoral visits, for example: Umberto Mazzone and Angelo Turchini, eds., Le visite pastorali: analisi di una fonte (Bologna: Il Mulino, 1991); on the Spanish Cuestionarios: Francisco de Solano, ed., Cuestionarios para la formación de las relaciones geográficas de Indias: siglos XVI/XIX (Madrid: Consejo Superior de Investigaciones Científicas, 1988); Howard F. Cline, "The Relaciones Geográficas of the Spanish Indies, 1577-8," Hispanic American Historical Review 44 (1964); Cline, "The Relaciones Geográficas of Spain, New Spain, and the Spanish Indies: An Annotated Bibliography," in Handbook of Middle American Indians, ed. Howard F. Cline and Robert Wauchope (Austin: University of Texas Press, 1972); Arndt Brendecke, Imperium und Empirie: Funktionen des Wissens in der Spanischen Kolonialherrschaft (Cologne: Böhlau, 20o9); Brendecke, "Informing the Council. Central Institutions and Local Knowledge in the Spanish Empire," in Empowering Interactions. Political Cultures and the Emergence of the State in Europe 1300-1900, ed. Willem Pieter Blockmans, André Holenstein, and Jon Mathieu (Farnham: Ashgate, 20o9); Antonio Barrera, "Empire and Knowledge: Reporting from the New World," Colonial Latin American Review 15, no. 1, June (2006); Antonio Barrera-Osorio, Experiencing Nature: The Spanish American Empire and the Early Scientific Revolution, 1st ed. (Austin: University of Texas Press, 2006); Barrera-Osorio, "Nature and Experience in the New World: Spain and England in the Making of the New Science," in Más allá de la Leyenda Negra: España y la revolución científica = Beyond the Black Legend; Spain and the Scientific Revolution, ed. Víctor Navarro Brotons and William Eamon (Valencia: Universitat de València, 2007); Barrera-Osorio, "Empiricism in the Spanish Atlantic World," in Science and Empire in the Atlantic World, ed. James Delbourgo and Nicholas Dew (New York: Routledge, 2008); Barrera-Osorio, "Knowledge and Empiricism in the Sixteenth-Century Spanish Atlantic World," in Science in the Spanish and Portuguese Empires, 1500-1800, ed. Daniela Bleichmar, Paula De Vos, Kristin Huffine, and Kevin Sheehan (Stanford: Stanford University Press, 2009). 
experience and for testing the adequacy of scientific generalizations." 4 In this context, questionnaires or "general heads" as instructions for travellers played an important role and became a useful tool for pursuing a systematic collection of empirical data in a region, in order to improve knowledge of it and to enable broader comparisons between different territories. ${ }^{5}$ Thirdly, especially after the "discovery" of the Americas, there was a rekindling of curiosity not only for "exotic" but also for local nature. An extensive knowledge of local flora and fauna, but also of minerals, local characteristics of the terrain, orology and hydrology called for new forms of empirical research methods. ${ }^{6}$ Besides "official" queries such as the Spanish Cuestionarios, and pastoral visits or queries for travellers, scholars developed questionnaires designed to collect material in view of writing a comprehensive civil and natural history of local territories. ${ }^{7}$

In my paper, I would like to highlight the common elements underlying the Spanish questionnaires, and the queries for collecting information about nature and people, which were also developed in the context of the Spanish America, and their appropriation in Britain and on the Continent. I deliberately

4 Steven Shapin, A Social History of Truth: Civility and Science in Seventeenth-Century England (Chicago, London: The University of Chicago Press, 1994), 245.

5 Michael Hunter, "Robert Boyle's 'Heads' and 'Inquiries', Robert Boyle Project, Occasional Papers, no. 1 (2005); Hunter, "Robert Boyle and the Early Royal Society: A Reciprocal Exchange in the Making of Baconian Science," The British Journal for the History of Science 40 (March 2007); Barbara J. Shapiro, A Culture of Fact: England, 1550-1720 (Ithaca, London: Cornell University Press, 200o), 72-76; Daniel Carey, "Inquiries, Heads, and Directions: Orienting Early Modern Travel," in Travel Narratives, the New Science and Literary Discourse: 1569-1750, ed. Judy A. Hayden (Farnham: Ashgate, 2012); Justin Stagl, "Vom Dialog zum Fragebogen: Miszellen zur Geschichte der Umfrage," Kölner Zeitschrift für Soziologie und Sozialpsychologie 31 (1979); Maurizio Bossi and Claudio Greppi, eds., Viaggi e scienza: le istruzioni scientifiche per $i$ viaggiatori nei secoli XVII-XIX (Florence: Olschki, 2005); Joan-Pau Rubiés, "Instructions for Travellers: Teaching the Eye to See," History and Anthropology 9, no. 2-3 (1996). In their works, Carey, Rubiés and Stagl analyse the origin of this type of questionnaires for travellers in the context of the ars apodemica; this topic is for my analysis of secondary importance. An edition in French of different questionnaires (Boyle, Woodward, Vallisneri) in: Silvia Collini and Antonella Vannoni, eds., Les instructions scientifiques pour les voyageurs (XVII $-X I X^{e}$ siècle) (Paris: L'Harmattan, 2005).

6 Alix Cooper, Inventing the Indigenous: Local Knowledge and Natural History in Early Modern Europe (Cambridge: Cambridge University Press, 2007); Brian W. Ogilvie, The Science of Describing: Natural History in Renaissance Europe (Chicago, London: The University of Chicago Press, 2006).

7 Travel instructions experienced renewed success with the ethnological questionnaires, especially during the 19th century. See: Claude Blanckaert, ed., Le terrain des sciences humaines: instructions et enquêtes (XVIII ${ }^{e}-X X^{e}$ siècle) (Paris: L'Harmattan, 1996); Adam Fox, "Printed Questionnaires, Research Networks, and the Discovery of the British Isles, 1650-180o," The Historical Journal 53, no. 3 (2010). 
use the term "appropriation" following Kosta Gavroglu's definition as "a form of the fusion of aspects of science and technology with local traditions," namely to denote an active and creative form of translation of these tools into other cultural contexts. ${ }^{8}$

Questionnaires are a good example of how to approach the topic "mapping people and territories" because they show the common origin of investigations into geography as well as civil and natural history of a territory. ${ }^{9}$ They also allow us to scrutinize the geographies of the development of empirical practices in the early modern age. Two aspects deserve particular attention, here. First, the role of the Spanish American empire as a place where new forms of empirical research emerged and were institutionalized. ${ }^{10}$ Secondly, the need to understand their development in a longue durée perspective, which can normalize the interpretation of the role of Britain and Bacon's empiricism and integrate other European peripheral territories (the Old Swiss Confederacy and the Italian Peninsula in the 18th century) in this process. In a wider sense, my paper wants to contribute to the discussion of provincializing Europe and of a pluralization of spaces in the geography of the history of knowledge, in which the different religious denominations can find a place. ${ }^{11}$

8 Kostas Gavroglu et al., "Science and Technology in the European Periphery: Some Historiographical Reflections," History of Science 46, no. 2 (2008): 159-6o.

9 See, for example, Charles W. J. Withers, Geography, Science, and National Identity: Scotland Since 1520, (Cambridge: Cambridge University Press, 2001); Withers, Placing the Enlightenment: Thinking Geographically About the Age of Reason (Chicago, London: The University of Chicago Press, 2007); David N. Livingstone, Putting Science in Its Place: Geographies of Scientific Knowledge (Chicago, London: The University of Chicago Press, 2003); Lissa Roberts, "Situating Science in Global History: Local Exchanges and Networks of Circulation," Itinerario 33, no. 1 (2009); Fa-ti Fan, "The Global Turn in the History of Science," East Asian Science, Technology and Society: An International Journal 6 (2012); René Sigrist, Eric Widmer, and Wladimir Berelowitsch, "Les lieux des sciences dans l'Europe moderne," in Lieux d'Europe: mythes et limites, ed. Stella Ghervas and François Rosset (Paris: Ed. de la Maison des sciences de l'homme, 2008).

10 For example: Brendecke, Imperium und Empirie; Jorge Cañizares-Esguerra, "Spanish America: From Baroque to Modern Colonial Science," in The Cambridge History of Science: Eighteenth-Century Science, ed. Roy Porter (Cambridge: Cambridge University Press, 2003); Cañizares-Esguerra, Nature, Empire, and Nation: Explorations of the History of Science in the Iberian World (Stanford: Stanford University Press, 2006); Cañizares-Esguerra, "Iberian Science in the Renaissance: Ignored How Much Longer?," Perspectives on Science 12, no. 1 (2004).

11 For more on the problem (and the Merton-Thesis), see:Dipesh Chakrabarty, Provincializing Europe: Postcolonial Thought and Historical Difference (Princeton: Princeton University Press, 200o); Steven Shapin, "The House of Experiment in Seventeenth-Century England," Isis 79 (1988); Ierome B. Cohen, ed., Puritanism and the Rise of Modern Science: The Merton Thesis (New Brunswick: Rutgers University Press, 199o); Edward B. Davis and 
From the earliest contacts with the New World, Spanish monarchs set up institutions to govern their territories, for instance the Consejo de Indias (1524), and demanded descriptions of them by sending official requests for reports on their geography, human settlements, and demography. Between $155^{\circ}$ and 1570, one may notice an institutionalization of information-gathering practices through questionnaires. This phase began in the mid-1540s with the questionnaire (1546) and Memorial of Alonso de Santa Cruz (c. 1500-1572). Santa Cruz's questionnaire was a pioneer for its format focused on the collection of natural history information, compared with other questionnaires with tax-related queries. ${ }^{12}$ It consisted of seventeen questions with a preliminary note ("advertencia"); it mentioned many relevant aspects to an understanding of the newly discovered territories: the geographical location of the villages, their names in the local languages, the determination of ports and places based on longitude and latitude, the hydrography of an area and its inundation risks. Other topics concerned the description of the lands and their geographical characteristics, rivers, lakes, springs, mountains and mines, minerals, and rocks. Several other queries examined flora, fruit, spices, and herbs, but also the indigenous population, their kingdoms and costumes. ${ }^{13}$ Between 1569 and 1577 , we find similar questions about people and natural history in the Cuestionarios prepared by Juan de Ovando y Godoy (1530-1575), appointed Visitor to the Council of the Indies, and by Juan López de Velasco (1530-1598), Cronista-Cosmógrafo of the Spanish crown. In 1569, Juan de Ovando y Godoy sent a questionnaire with 31 chapters, asking for information about people, demographics, and ecclesiastical institutions to several jurisdictions in Mexico. A couple of years later, and helped by López de Velasco, his former secretary, he produced a new version of

Michael P. Winship, "Early Modern Protestantism," in Science and Religion: A Historical Introduction, ed. Gary B. Ferngren (Baltimore: Johns Hopkins University Press, 2002); Kapil Raj, "Relocations," in Science and Technology Studies: Critical Concepts in the Social Sciences, ed. Michael Lynch (London: Routledge, 2012), IV; Raj, "Thinking Without the Scientific Revolution: Global Interactions and the Construction of Knowledge," Journal of Early Modern History 21 (2017); Raj, "Quand l'amérique a inventé la science européenne," in Europa: une autre histoire, ed. Jakob Vogel, Thomas Serrier, and Etienne François (Paris: Les Arènes, 2017).

12 Carmen Millán de Benavides, Epítome de la Conquista del Nuevo Reino de Granada: la cosmogonía española del Siglo XVI y el conocimiento por cuestionario (Bogotá: Pontificia Universidad Javeriana, Instituto de Estudios Sociales y Culturales Pensar, 2001).

13 Raquel Álvarez Peláez, La conquista de la naturaleza americana (Madrid: Consejo Superior de Investigaciones Científicas, 1993). 
the document, the Ordenanzas para la formación del libro de las Descripciones de las Indias (1573) with 135 questions, and sent it to Peru. ${ }^{14}$

These questionnaires were a part of an ambitious reform program that Ovando introduced in the 156os: visiting and reforming the University of Alcalá (1564-1565), the reformation of the Consejo de Indias (1566-1571), and the scientific expedition to America of the medical attendant ("protomedico") of Philip II, Francisco Hernández (1517-1584) between 1570 and $1577 .{ }^{15}$ In May 1577, the same López de Velasco was responsible for the publication of the key document in this tradition, the Instrucción y Memoria de las Relaciones que se han de hacer para la descripcion de la Indias. ${ }^{16}$ If we look more closely at the 50 questions of this Cuestionario, we will find almost all the topics already present in Santa Cruz's questionnaire. Several questions concerned the

14 Solano, Cuestionarios para la formación de las relaciones geográficas de Indias, 11-15, 16-74; Pilar Ponce Leiva, "Las Ordenanzas sobre descripciones (1573). Su aplicación en la Real Audiencia de Quito," in Solano, Cuestionarios para la formación de las relaciones geográficas de Indias, ed. Solano, Cuestionarios para la formación de las relaciones geográficas de Indias, LXXIX-XCI. Raquel Álvarez Peláez, "El Cuestionario de 1577. La 'Instruccion y memoria de las relaciones que se han de hacer para la descripcion de las Indias' de 1577," in Solano, Cuestionarios para la formación de las relaciones geográficas de Indias; Barbara E. Mundy, The Mapping of New Spain: Indigenous Cartography and the Maps of the Relaciones Geográficas (Chicago, London: The University of Chicago Press, 1996); Burke, A Social History of Knowledge, 116-49.

15 Hernández brought sixteen volumes with drawings and observations back to Spain, including the descriptions of 3000 new species of plants and 500 new species of animals. His work was published posthumously: Francisco Ximenez, Quatros libros de la naturaleza, $y$ virtudes de las plantas, $y$ animales que estan receuidos en el vso de medicina en la Nueva España, y la methodo, y correcion y preparacion, que para administrallas se requiere con lo que el Doctor Francisco Hernandez escrivio en lengua latina (Mexico: Vid. Daualos, 1615). The Latin translation of the book was made by Federico Cesi, the founder of the Accademia dei Lincei in Rome: Francisco Hernández, Nova plantarum, animalium et mineralium Mexicanorum historia a Francisco Hernandez medico in Indiis praestantissimo primum compilata, dein a Nardo Antonio Reccho in volumen digesta (Romae: sumptibus Blasii Deversini, \& Zanobii Masotti, typis Vitalis Mascardi, 1651); Jesús Bustamante García, "Francisco Hernández, Plinio del Nuevo Mundo: tradición clásica, teoría nominal y sistema terminológico indígena en una obra renacentista," in Entre dos mundos: fronteras culturales y agentes mediadores, ed. Berta Ares Queija and Serge Gruzinski (Sevilla: Escuela de Estudios Hispano-Americanos, 1997); Antonio Clericuzio, "Le accademie scientifiche del Seicento," in Il contributo italiano alla storia del pensiero. Scienze, ed. Antonio Clericuzio and Saverio Ricci (Rome: Istituto della Enciclopedia Italiana fondata da Giovanni Treccani, 2013); Luigi Guerrini, "Piante e animali del Nuovo Mondo. Federico Cesi e il Tesoro messicano," in Le scienze, vol. 5, ed. Antonio Clericuzio and Germana Ernst (Treviso: Colla, 2008).

16 The Spanish crown will continue using questionnaire as an administrative tool until 1812. Solano, Cuestionarios para la formación de las relaciones geográficas de Indias, 79-87. 
geographical coordinates of places, their climate, and the quality of the soil. The queries also asked about the presence of mountains, springs, lakes, rivers, and about the vegetation, medicinal plants, and mines. There were also a series of questions examining the customs of the inhabitants.

At the same time, questionnaires were implemented and used by different actors involved in the evangelization, exploration and/or colonization of New Spain. The Franciscan friar Bernardino de Sahagún (c. 1499-159o), a missionary priest who participated in the Catholic evangelization of colonial Mexico, provides a very interesting example of this research practice. He worked on his Historia general de las cosas de Nueva España (first version 1576, second, revised version, 1585) by means of a "formulario de preguntas" (a questionnaire), which could be reconstructed from his book. Sahagún sent it to Indian villages. In his research practice, questionnaires are very valuable instruments, designed not only to investigate the religious or political organization of local communities but also to understand the "potential" of the land, i.e. local flora, fauna and minerals, involving local informants. ${ }^{17}$ In this sense, we observe a simultaneous rise of questionnaires as information-gathering tools on an official level (in Spain's colonial state building) and on a more informal level in the context of early modern ethnological or natural history research by scholars, travellers, clergymen or friars. Like Sahagún, other naturalists - for example the British Robert Plot (1640-1696), the Swiss Johann Jakob Scheuchzer

17 For more on Sahagún: Florencio Vicente Castro, Bernardino de Sahagún primer antropólogo en Nueva España (siglo XVI) (Salamanca: Ed. Universidad de Salamanca, Institucíon “Fray Bernardino de Sahagún", Excma. Diputación provincial de León, 1986). Miguel León Portilla, Bernardino de Sahagún, Protagonistas de América (Madrid: Historia 16, 1987); Alfredo López Austin, "Estudio acerca del método de investigación de fray Bernardino de Sahagún," in La investigación social de campo en México, ed. Jorge Martínez Ríos (México: Universidad Nacional Autónoma, 1976); López Austin, "Estudio acerca del método de investigación de fray Bernardino de Sahagún," Estudios de Cultura Náhuatl 42 (2011); José M. López Piñero, "Sahagún, Bernardino de," in Diccionario histórico de la ciencia moderna en España, vol. 2, ed. José M. López Piñero (Barcelona: Ed. Península, 1983); Bernardino de Sahagún, Florentine Codex: General History of the Things of New Spain, transl. from the Aztec into English, with notes and ill. by Arthur James Outram Anderson, and Charles E. Dibble, 1. paperback ed. (Salt Lake City: University of Utah Press, 2012), 1-13. English edition of Sahagún's Historia general: Bernardino de Sahagún, The Conquest of New Spain, 1585 Revision, ed. Howard F. Cline (Salt Lake City: University of Utah Press, 1989). For more on questionnaires and lists as "social and material technology," especially in the context of 17th-Century British natural history, see: Elisabeth Yale, "Making Lists: Social and Material Technologies in the Making of Seventeenth-Century British Natural History," in Ways of Making and Knowing: The Material Culture of Empirical Knowledge, ed. Pamela H. Smith, Amy R. W. Meyers, and Harold J. Cook (Ann Arbor: University of Michigan Press, 2014). 
(1672-1733) or the Italian Antonio Vallisneri (1661-1730) - used questionnaires and tried to involve local informants in their projects.

The implementation of questionnaires to obtain information about the territory, nature, and people was also an important element for the constitution of the Spanish colonial empire. In an inspiring article (1998), Bustamante García defined this process as a collective enterprise during Philip II's reign, aimed at establishing the monarchy and underpinning its legitimacy. Bustamante García claims that four factors were crucial for this process. First, the mathematization of space and its resources as a new form of political science (the Relaciones geográficas are an aspect of this); secondly, control over nature and the development of natural history research and of inventories of resources; third, control over time and the constitution of an "official" historical narrative. Finally, and no less importantly, he indicates the creation of a proper Spanish juridical and intellectual tradition. The first two factors are particularly interesting for our purpose: the mathematization of space and of its resources and control over nature alongside the development of natural history research and of inventories of resources. As Bustamante García rightly underlined, these fields are exactly "the same that France and England - from the Académie Royale des Sciences and the Royal Society - assumed as state projects in the succeeding two centuries and that are usually associated with the culmination of the so-called Scientific Revolution." ${ }^{18}$

In this sense, Bustamante García as well as new studies by Cañizares-Esguerra, Barrera-Osorio and, in the German speaking area, by Brendecke, confirm the role of colonial Spain in the development of a "new" form of empiricism, and challenge - once more - the role of Britain in the "so-called Scientific Revolution." ${ }^{19}$ Particularly, Barrera-Osorio stressed the development of empirical strategies by pilots, natural historians and entrepreneurs and the fact that the Spanish Crown incorporated these strategies "in the structure of the imperial bureaucracy for collecting information." ${ }^{20}$

18 Jesús Bustamante García, "La empresa naturalista de Felipe II y la primera expedición cientifica en suelo americano. La creación del modelo expedicionario renacentista," in Felipe II (1527-1598): Europa y la monarquía católica, ed. José Martinez Millán (Madrid: Editorial Parteluz, 1998), 40: "los mismos que Francia e Inglaterra - desde la Académie Royale des Sciences y la Royal Society - asumieron como proyectos de Estado en los dos siglos siguientes y que habitualmente se asocian a la culminación de la llamada Revolución Científica." My translation.

19 Barrera-Osorio, Experiencing Nature; Brendecke, Imperium und Empirie; CañizaresEsguerra, "Iberian Science in the Renaissance: Ignored How Much Longer?".

Barrera, "Empire and Knowledge: Reporting from the New World", 43. 
As I will show in the next subchapters, while questionnaires were initially implemented as official information gathering tools in the early-modern statebuilding process, they continued their career as scholars' field research tools within the Royal Society in Britain and, later, on the European Continent. Johann Jakob Scheuchzer, the first naturalist to import the questionnaire method into the German-speaking world, knew the contemporary literature about natural history research in the Americas. In his Historiae helveticae naturalis prolegomena (1700), Scheuchzer mentioned Francisco Hernández' work and in his Bibliotheca scriptorum historiae naturali (1716), an international bibliography of natural history organized in chapters depending of the different continents, he mentioned not only Hernández but also the publications of Juan Fragoso (c. 1530-1597), a personal physician of Philip II of Spain. ${ }^{21}$

\section{$2 \quad$ Queries in Britain}

Interest in the Spanish colonial enterprise and the role of travels and travel narratives as (almost) reliable sources for compiling a comprehensive natural history played a similar central role in Britain during the 17 th century. We can see a "chronological coincidence between European expansion and the institutionalization of empirical practices in European kingdoms." 22 Translations

21 Johann Jakob Scheuchzer and Johann Rudolf Lavater, Historiae helveticae naturalis prolegomena publicae Eruditorum Syzētēsei subiecta praeside I. Iacobo Scheuchzero [...], Respondente Iohanne Rodolfo Lavatero [...] In Auditorio Aestivo H.L.Q.S. Die Septembr. (Tiguri: Gessner, 1700), 17-19; Johann Jakob Scheuchzer, Bibliotheca scriptorum historiae naturalis omnium Terrae Regionum inservientium; historiae naturalis Helvetiae Prodromus; accessit Celeberrimi Viri Jacobi Le Long, Bibliothecarii Oratoriani de Scriptoribus historiae naturalis Galliae; collegit Johann Jakob Scheuchzer, Med. D. Math. Prof. Societ. Leopoldino-Carolinae, Regiae Angl. \& Boruss. (Tiguri: Typis Henrici Bodmeri, 1716), 200o2, 211. He mentions Hernández' 1615 edition; Ximenez, Quatros libros de la naturaleza, $y$ virtudes de las plantas, $y$ animales que estan receuidos en el vso de medicina en la Nueva España, y la methodo, y correcion y preparacion, que para administrallas se requiere con lo que el Doctor Francisco Hernandez escrivio en lengua latina and the Italian edition of 1649 and 1651; Francisco Hernández, Rerum medicarum Novae Hispaniae thesaurus seu plantarum animalium mineralium Mexicanorum historia (Rome: Officina carte valori dell'Istituto Poligrafico e Zecca dello Stato, 1992 [1649]); Francisco Hernández, Nova plantarvm, animalivm et mineralivm Mexicanorvm historia: cui demum accessere aliqvot ex Principis Federici Casii Frontispiciis Theatri naturalis phytosophicce tabulce; vna cum quamplurimis iconibus, ad octingentas [...] exhibentur (Romae et al.: Mascardus, 1651) and Juan Fragoso, Discurso de las cosas aromaticas, arboles y frutales [...] (Madrid: Francisco Sanchez, 1572), in its Latin translation of 1610. 
of several books relating to the East and West Indies by Richard Eden (c. 15201576) and by Samuel Purchas (1577-1626) as well as the publication of José de Acosta's work in an English version (The Naturall and Morall Historie of the East and West Indies, London, 1604) were circulating in Britain, facilitating the reception of this empirical culture. ${ }^{23}$

Francis Bacon (1561-1626) was conscious of the importance of travel and travel explorations as instruments for acquiring new forms of knowledge of the world. He was also aware of their importance in securing first-hand information about newly discovered territories and, more generally, about "exotic" countries. ${ }^{24}$ In his text Of Travel (1601), he compiled a list of "things to be seen and observed" during a tour. ${ }^{25}$ In the Parasceve ad historiam naturalem et experimentalem (1620), he not only put together a series of suggestions about how to write comprehensive civil and natural history, but also named a series of topics underlining their usefulness for achieving such a commitment. He also emphasized the role of "factors and merchants to go everywhere in search of them [the materials] and bring them in." ${ }^{26}$ Bacon also pointed out a range

23 Richard Eden, The Decades of the Newe Worlde or West India: Conteyning the Nauigations and Conquestes of the Spanyardes, [...] Translated into Englysshe by Richarde Eden (London: In ædibus Guilhelmi Powell, Anno. 1555); Samuel Purchas, Purchas His Pilgrimes: In Fiue Bookes. (London: Printed by William Stansby for Henrie Fetherstone, 1625); the original text of Acosta is: José de Acosta, Historia natural y moral de las Indias, [Reproducción en facsimil], introd., apéndice y antología por Barbara G. Beddall, Hispaniae scientia (Valencia: Albatros, 1977 [159o]).

24 In his Novum Organon, he wrote: "Rursus vero homines a progressu in scientiis detinuit et fere incantavit reverentia antiquitatis, et virorum qui in philosophia magni habiti sunt authoritas, atque deinde consensus. [...] Neque pro nihilo aestimandum, quod per longiquas navigationes et peregrinationes (quae seculis nostris increbuerunt) plurima in natura patuerint, et reperta sint, quae novam philosophiae lucem immittere possint." Francis Bacon, Novum Organum, sive indicia vera de interpretatione naturae, Part 1, LXXXIV. In: Francis Bacon, The Works of Francis Bacon, vol. 1, ed. coll. and ed. James Spedding, Robert Leslie Ellis, and Douglas Denon Heath, 15 volls. (Boston: Houghton, Mifflin and Company, 1857-1882), 290-91. Translation, vol. viII, 116-17: "Again, men have been kept back as by a kind of enchantment from progress in the sciences by reverence for antiquity, by the authority of men accounted great in philosophy, and then by general consent. [...] Nor must it go for nothing that by distant voyages and travels which have become frequent in our times, many things in nature have been laid open and discovered which may let in new light upon philosophy."

25 For example, he asked about the "courts of princes," "courts of justice," but also church and monasteries, antiquities and ruins, libraries, cabinets and rarities, havens and harbors, antiquities and ruins, shipping and navies: Francis Bacon, "Of Travel" in The Philosophical Works of Francis Bacon, ed. John M. Robertson, Repr. from the texts and transl., with the notes and prefaces, of Ellis and Spedding (London: Routledge, 1905), 756-57.

26 Bacon, The Works of Francis Bacon, vol. 2, 44: "At intellectus materialia tam late patent ut ea (tamquam per procuratores et mercatores) undiqui conquiri et importari debeant. 
of queries (topica particularia or Articuli Inquisitionis) and in his Historia naturalis et experimentalis ad condendam philosophiam (London, 1622), published as Part III of his Instauratio magna, intended to define the state of research in the natural sciences and at the same time to promote new ones. ${ }^{27}$ Once again, in his utopian novel Nova Atlantis (1627) or, in English, New Atlantis (1628), which begins with the description of an overseas expedition from Peru to China and Japan, he underlines several times the importance of voyages to collect books, information and "patterns of experiments" from all parts of the world. In this text, we can read: "[...] we have twelve [fellows] that sail into foreign countries, under the names of other nations, (for our own we conceal); who bring us the books, and abstracts, and patterns of experiments of all other parts." ${ }^{28}$

Bacon's scheme for collecting data and the influence of questionnaires as information-gathering tools are evident in the activity of the Hartlib circle and in the early years of the Royal Society. After 1645, the brothers Gerard

Accedit etiam illud, quod coeptis nostris vix dignum esse aestimemus ut in re tali quae fere omnium industriae pateat nos ipsi tempus teramus. Quod autem caput rei est ipsi nunc praestabimus; ut eijusmodi historiae modum et descriptionem, qualis intentioni nostrae satisfaciat diligente et exacte proponamus." For the list of topics: Bacon, The works of Francis Bacon, vol. 2, 61-69; Translation: Bacon, The works of Francis Bacon, vol. vilI (Translations of the philosophical Works, vol. 1), 354: "[...] but the materials on which the intellect has to work are so widely spread, that one must emply factors and merchants to go everywhere in search of them and bring them in. Besides I hold it to be somewhat beneath the dignity of an undertaking like mine that I should spend my own time in a matter which is open to almost every man's industry." List of topics, $373^{-81}$.

27 Francisci Baconi, Historia naturalis et experimentalis ad condendam philosophiam siue, phcenomena vniuersi: quce est Instauratoinis magnce pars tertia Londini: In officina Io. Hauiland, impensis Matthæi Lownes \& Guilielmi Barret, 1622; Hunter, "Robert Boyle and the Early Royal Society: A Reciprocal Exchange in the Making of Baconian Science"; Hunter, "Robert Boyle's 'Heads' and 'Inquiries'. The bibliography on this topic (travel and science) is huge, and I shall mention only a few: Rob Iliffe, "Science and Voyages of Discovery," in The Cambridge History of Science: Eighteenth-Century Science, ed. Roy Porter (Cambridge: Cambridge University Press, 2003); Marie-Noëlle Bourguet, "Voyages lointains et mesure du monde: la projection du regard européen sur le monde (vers 150o-vers 180o)," in L'Europe des sciences et des techniques $X V^{e}-X V I I I^{e}$ siècle: un dialogue des savoirs, ed. Liliane Hilaire-Pérez, Fabien Simon, and Marie Thébaud-Sorger (Rennes: Presses universitaires de Rennes, 2016).

28 Francis Bacon, New Atlantis: A Work Unfinished (London: Printed by Tho. Newcomb, 1658), 32; for the Latin text: Francisci Baconi, Nova Atlantis (Turnhout: Brepols Publishers, 2014); about this work, for example: Josef Bordat, "Bacons Atlantis-Mythos und das Selbstverständnis der modernen Wissenschaft," in Mythos - Helden - Symbole Legitimation, Selbst- und Fremdwahrnehmung in der Geschichte der Naturwissenschaften der Medizin und der Technik, ed. Siegfried Bodenmann and Susan Splinter (Munich: Martin Meidenbauer, 2009). 
(1604-1650) and Arnold Boate (16o6-1653) were working on a comprehensive natural history of Ireland, which Gerald published in $165^{2} .{ }^{29}$ At the same time, Arnold, hoping to collect enough information to complete the project, composed the first British questionnaire, An Interrogatory Relating more particularly to the Husbandry and Natural History of Ireland, published as an appendix to the second edition of Hartlib's Legacie. ${ }^{30}$

The work of gaining information in a more systematic way in the context of the British colonial expansion also prompted the Royal Society to draw up a series of "articles of inquiry," which provided a set of topics around which to organize observations. In 1661, the Society created a committee (whose members included Sir Robert Moray, William Petty, Laurence Rooke, Thomas Povey, Robert Boyle, John Wilkins, John Evelyn and Henry Oldenburg, first secretary of the Society and editor of the Philosophical Transactions) with the purpose of considering "proper questions to be inquired of in the remotest parts of the world." It is worth noticing that this committee was created at the same time as the Council for Foreign Plantations and not by accident; both institutions shared some members, like Robert Boyle and Thomas Povey. British scholars, merchants and the British Monarchy had a strong scientific (medical), economic and political interest in the resources of the newly discovered territories and in extra-European natural history (especially in botany). ${ }^{31}$

29 Gerard Boate, Irelands Naturall History: Being a True and Ample Description of Its Situation, Greatness, Shape, and Nature, of Its Hills, Woods, Heaths, Bogs [...] With Its Heads or Promontories, Harbours, Roades, and Bayes [...] Of Its Metalls, Mineralls [...] Turf [...] And Lastly, of the Nature and Temperature of Its Air and Season, and What Diseases It Is Free From, or Subject Unto (London: For John Wright, 1652).

30 Fox, "Printed Questionnaires, Research Networks, and the Discovery of the British Isles, 1650-180o," 595-96; Charles Webster, The Great Instauration: Science, Medicine and Reform, 1626-166o, 2nd ed., 1st ed. 1975 (Oxford: Peter Lang, 2002), 428-31; Arnold Boate, "An Interrogatory Relating more particularly to the Husbandry and Natural History of Ireland," in Samuel Hartlib His Legacie, Or, an Enlargement of the Discourse of Husbandry Used in Brabant \& Flaunders: Wherein Are Bequeathed to the Common-Wealth of England More Outlandish and Domestick Experiments and Secrets in Reference to Universall Husbandry, ed. Samuel Hartlib, Cressy Dymock, Robert Child, and Richard Weston, eds., The 2nd ed., augmented with an appendix (London: Printed by R. \& W. Leybourn for Richard Wodenothe, 1652), Appendix, without pagination.

31 On the relationship between colonial empires and botany, for example:Lucile H. Brockway, Science and Colonial Expansion: The Role of the British Royal Botanic Gardens, 2nd ed. (1st ed. 1979) (New Haven, London: Yale University Press, 2002). Londa Schiebinger and Claudia Swan, eds., Colonial Botany: Science, Commerce, and Politics in the Early Modern World (Philadelphia: University of Pennsylvania Press, 2005). Samir Boumediene, La colonisation du savoir une histoire des plantes médicinales du "Nouveau Monde" (1492-1750) (Vaulx-en-Velin: Les éditions des mondes à faire, 2016). 
The most famous questionnaire produced in the context of the Royal Society is Robert Boyle's General Heads for a Natural History of a Country, Great or Small of (first published in 1665-1666). ${ }^{32}$ The English questionnaires are rather similar to those developed by the Spanish scholars. ${ }^{33}$ Like the Spanish questionnaire of 1577 and the questionnaires of Alonso de Santa Cruz, Boyle's queries contain a group of questions relating to "Supraterraneous, Terrestrial, and Subterraneous" topics. ${ }^{34}$ In addition, he proposed queries about the heavens and air (i.e. weather, climate, winds, and diseases related to the weather or the occurrence of meteors) as well as about water and springs. Another group of questions related to the Earth, its configuration (dimensions, orology, the nature of soil), and its production, such as minerals, stones and mines (and it is not by chance that, in his questionnaire, Boyle refers to the technique used to separate "the Nobler from the Baser Metals" in Peru). ${ }^{35}$ The "terrestrial questions" also included the inhabitants, the vegetation and the animals

$3^{2}$ In 1692, these queries were published with a supplement of later questionnaires printed in the Philosophical Transactions. Robert Boyle, General Heads for the Natural History of a Country Great or Small: Drawn Out for the Use of Travellers and Navigators / Imparted by [...] Robert Boyle [...]; to Which Is Added, Other Directions for Navigators, Etc. With Particular Observations of the Most Noted Countries in the World; by Another Hand (London: Printed for John Taylor [...] and S. Hedford, 1692); Boyle, "General Heads for a Natural History of a Countrey, Great or Small, Imparted Likewise by Mr. Boyle," Philosophical Transactions 1, no. 11 (1665); Boyle, "Other Inquiries Concerning the Sea," Philosophical Transactions 1, no. 18 (1665); "Inquiries for Suratte, and Other Parts of the East-Indies; Inquiries for Persia. - Inquiries for Virginia and the Bermudas. For Guaiana and Brasil," Philosophical Transactions 2, no. 23 (1666); "Inquiries of Directions for the Ant-Iles, or Caribe-Islands," Philosophical Transactions 3, no. 33 (1668); Daniel Carey, "Compiling Nature's History: Travellers and Travel Narratives in the Early Royal Society," Annals of Science 54, no. 3 (1997), 274; Boyle's questionnaire was addressed to travellers by sea and overland. About the different queries produced by members of the Royal Society: Thomas Birch, The History of the Royal Society of London for Improving of Natural Knowledge [Facsimile], 4 vols. (Bruxelles: Culture et civilisation, 1967-1968), vol. 1 (original edition: London, 1756-1757), 15 (for the quotation on p. 34), 68, 69, 79, 119, 130, 144, 165-66, 180, 192, 199, 297-98, and 318-19.

33 Barbara J. Shapiro, "History and Natural History in Sixteenth and Seventeenth-Century England: An Essay on the Relationship Between Humanism and Science," in English Scientific Virtuosi in the 16th and 17th Centuries: Papers Read at a Clark Library Seminar, 5 February 1977, ed. Barbara J. Shapiro and Robert G. Frank (Los Angeles: University of California, William Andrews Clark Memorial Library, 1979), 7 .

34 "The things, to be observ'd in such a [natural] History, may be variously (and almost at pleasure) divided: As, into Supraterraneous, Terrestrial, and Subterraneous; and otherwise: but we will at present distinguish them into those things, that respect the Heavens or concern the Air, the Water, or the Earth," Boyle, "General Heads for a Natural History of a Countrey, Great or Small, Imparted Likewise by Mr. Boyle," 186.

Boyle, General Heads, 41. 
of a territory. Boyle asked for information on the correct determination of a geographical place (i. e. the coordinates of a place, "what fixt stars are and what not seen there"). ${ }^{36}$

Following these examples, Robert Plot, first Professor of Chemistry at the University of Oxford, Fellow of the Royal Society and the first Keeper of the Ashmolean Museum, wrote and printed questionnaires while preparing his studies on the natural history of Oxfordshire (published in 1677) and of Staffordshire (printed in 1686). ${ }^{37}$ In his first printed questionnaire Questions to be asked to the most ingenious of each County in my Travels through England, Robert Plot, like in the Spanish and Robert Boyle's queries, first asked questions regarding the quality of the air and the weather (heaven). Plot was looking for firsthand information from seamen ("Enquire of Seamen," he wrote in his questionnaire) concerning navigation (tides, ebbs, currents), the recurrence of storms, and the presence of echoes. With these questions, Plot was following the Directions for Sea-men, bound for far Voyages of Laurence Rooke, also published in the Philosophical Transactions in 1665-1666.38

Other questions concerned the saltiness of the sea, the typology of the different fountains (springs), orography ("mountains, caves, barrows"), the quality of the earth, the presence of stones, gems and metals. Other points of interests were "strange or prodigious trees," "other curiosity in husbandry," and the different species of insects (especially bees and silkworms). The final questions of this first questionnaire concerned the inhabitants of the different regions (the presence of monsters, giants, hermaphrodites) and British, Roman or Saxon antiquities. Plot printed a second questionnaire, similar to this first one, after finishing his History of Oxford-Shire ("Enquiries to be propounded to the most

36 Boyle, General Heads, 17.

37 Robert Plot, The Natural History of Oxford-Shire:Being an Essay Toward the Natural History of England (Oxford: At Mr. S. Millers, 1677); Plot, The Natural History of Stafford-Shire (Oxford: Printed at the Theater, 1686); for Plot's biography: A. J. Turner, "Plot, Robert (Bap. 1640, D. 1696)," in The Oxford Dictionary of National Biography, ed. H. C. G. Matthew and B. Harrison (Oxford: Oxford University Press, 2004), https://doi.org/10.1093/ ref:odnb/22385, accessed on 23 September 2019; A. G. Keller, "Plot, Robert," in Complete Dictionary of Scientific Biography, ed. Charles Coulston Gillispie (Detroit: Charles Scribner's Sons, 2008); for the questionnaires: Archives of the Royal Society, London, Classified Papers (Cl.P.), vol. XIX "Inquiries and Answers, December 24, 1662 - May 25, 1692". See: Cl.P. XIX/19/93: "Questions to be asked to the most ingenious of each county in my travels through England" by R[obert] P[lot]; Cl. P. XIX/19/94: "Enquiries to be propounded to the most Ingenious of each County in my Travels through England and Wales, in order to their History of Nature and Arts" by R[obert] P[lot].

38 Laurence Rooke, "Directions for Sea-Men, Bound for Far Voyages," Philosophical Transactions 1, no. 8 (1665-1666), 141-42. 
Ingenious of each County in my Travels through England and Wales, in order to their History of Nature and Arts"). This questionnaire is organized in ten chapters: "Heaven and Air," "Waters," "Earth and Minerals," "Metals," "Stones," "Plants," "Husbandry," "Animals," "Arts," and "Antiquities." At the end of his flyer, Plot refers to his previous work about Oxfordshire and asks for the help of anyone who might be interested: their task is to "answer as many of them [questions] as they can, distinctly, according to the best of their skill." Replies have to be written "in a Paper apart, to lie ready against the Undertaker of this Design [Plot himself] shall call for them, in case they should then be absent from home."39

\section{Queries and Natural History on the Continent}

Henry Oldenburg (1619-1677), first secretary of the Society and editor of the Philosophical Transactions, acted as the broker (or the trait d'union) between Britain and the Continent in these years. He tried to export the model of the empirical way to investigate local territories, especially by exploiting his widespread correspondence network. One strategy was to send his correspondents copies of Robert Plot's Natural History of Oxford-Shire (Oxford, 1677) as a model for local investigations. ${ }^{40}$

Johann Jakob Wagner (1641-1695), doctor of the foundling hospital in Zurich and curator of that city's public library and museum (Bürgerbibliothek and Kunstkammer), attests a very early appropriation of this empirical way to investigate natural history in Switzerland. Wagner was active at the same time as

39 At the end of the text, Plot writes: "If anybody desire to be further informed in the nature of this Design, let him consult the Natural History of Oxford-Shire already extant [...]"; Archives of the Royal Society, London, Classified Papers, Cl. P. XIX/19/94: "Enquiries to be propounded to the most Ingenious of each County in my Travels through England and Wales, in order to their History of Nature and Arts" by R[obert] P[lot], without pagination. Keller, "Plot, Robert".

40 See: Alix Cooper, "Fragen ohne Antworten: Die Suche nach lokalen Informationen in der frühen Aufklärung," in Vor Google: Eine Mediengeschichte der Suchmaschine im analogen Zeitalter, ed. Thomas Brandstetter (Bielefeld: transcript, 2012). In the edition of Oldenburg's correspondence we can find several letters to Boyle, Hevelius, and other scholars, about queries and questionnaires, with some answers received from several physicians and naturalists; Alfred Rupert Hall and Marie Boas Hall, eds., The Correspondence of Henry Oldenburg, 13 vols. (Philadelphia: Taylor \& Francis, 1965-1986), vol. 3 (1666-1667), 47, 49, 58, 65, 729 (queries for Hevelius), 87, 248-57 (answers by Hevelius) 340-41, 553-61 (answers by Peter Möller), 562-71 (answers by Michael Behm) and vol. 4 (1667-1668), 133, 166-68, 275, 306, 419-24, vol. 5 (1668-1669), 82-83, 105-07, 200, 285, 303, 326, 422-26, $474-76$. 
Plot and is the author of the first natural history of the Old Swiss Confederacy, the Historia naturalis Helvetiae curiosa (1680). In his book, he programmatically expressed his intention to follow Bacon in his commitment to write a novel natural history, applying the inductive method. In the first lines of his Dedicatio, he mentions Bacon as the most important figure in this field and he acknowledges the influence of his De dignitate et augmentis scientiarum on his personal work. Three years later, Wagner's book was glowingly reviewed in the Philosophical Transactions; its Baconian leanings were recognized and appreciated by the reviewer. ${ }^{41}$ Interestingly, the sequence of topics in some chapters of his book closely mirror the organization of topics that we could find in the English questionnaires and in Plot's natural histories.

His successor as a doctor of the city of Zurich's foundling hospital, as curator of the public library and museum and as supporter of an empirical method to study nature was Johann Jakob Scheuchzer (1672-1733). Following the model of the Royal Society, in 1699 Scheuchzer published a questionnaire in Latin and German with approximately 190 questions, to investigate the natural history of the Old Swiss Confederacy, the first text of this kind in the German-speaking area. Like Wagner's book, Scheuchzer's Einladungsbrief zur Erforschung natürlichen Wunderen, so sich im Schweizer-Land befinden (1699, in Latin Charta invitatoria) begins with a reference to Bacon and the English questionnaires (fig. 2.1). ${ }^{42}$ Furthermore, the author mentions the successful commitment of the members of the Royal Society to guide their compatriots and foreigners in making observations of all phenomena at sea and on land, of air, animals, plants, and minerals. Scheuchzer cultivated a close intellectual exchange with several members of this academy, especially with John Woodward (1665-1728),

41 Johann Jacob Wagner, Historia naturalis Helvetiae curiosa (Tiguri: Joh. Henrici Lindinneri, 168o): Dedicatio (not paginated) [p. 1]: "Ad Scientiæ Naturalis exactam notitiam comparandam, multorum præclarorum Virorum, rerum naturalium maxime peritorum, judiciô, inter quos Magnus ille Angliæ Cancellarius, Franciscus Baconus, Baro de Verulamio (de Augmento Scientiarum Lib. II. C. 3) facile principem obtinet locum, ere maxime foret, si Historia Naturalis Inductiva cujuslibet regionis, quantum fieri poterit exactissima adornaretur, quo ex variis Observationibus \& Experimentis inde collectis Regulæ tandem certae \& indubitatæ elicit, Systemaque absolutum componi ac perfici queam." (Italic in the original text); for Wagner's review: "[An Account of Four Books]," Philosophical Transactions 13, no. 143-54 (1683).

42 Johann Jakob Scheuchzer, Charta invitatoria, quaestionibus, quae historiam Helvetiae naturalem concernunt, praefixa (Tiguri: [D. Gessner], 1699); Johann Jakob Scheuchzer, Einladungs-Brief, zu Erforschung Natürlicher Wunderen, so sich im Schweizer-Land befinden (Tiguri: [D. Gessner], 1699); a recent edition of the German version of the text in: Simona Boscani Leoni, ed., "Unglaubliche Bergwunder": Johann Jakob Scheuchzer und Graubünden. Ausgewählte Briefe 1699-1707, Cultura alpina Band 9 (Chur: Verlag Bündner Monatsblatt, 2019), 33-49. 


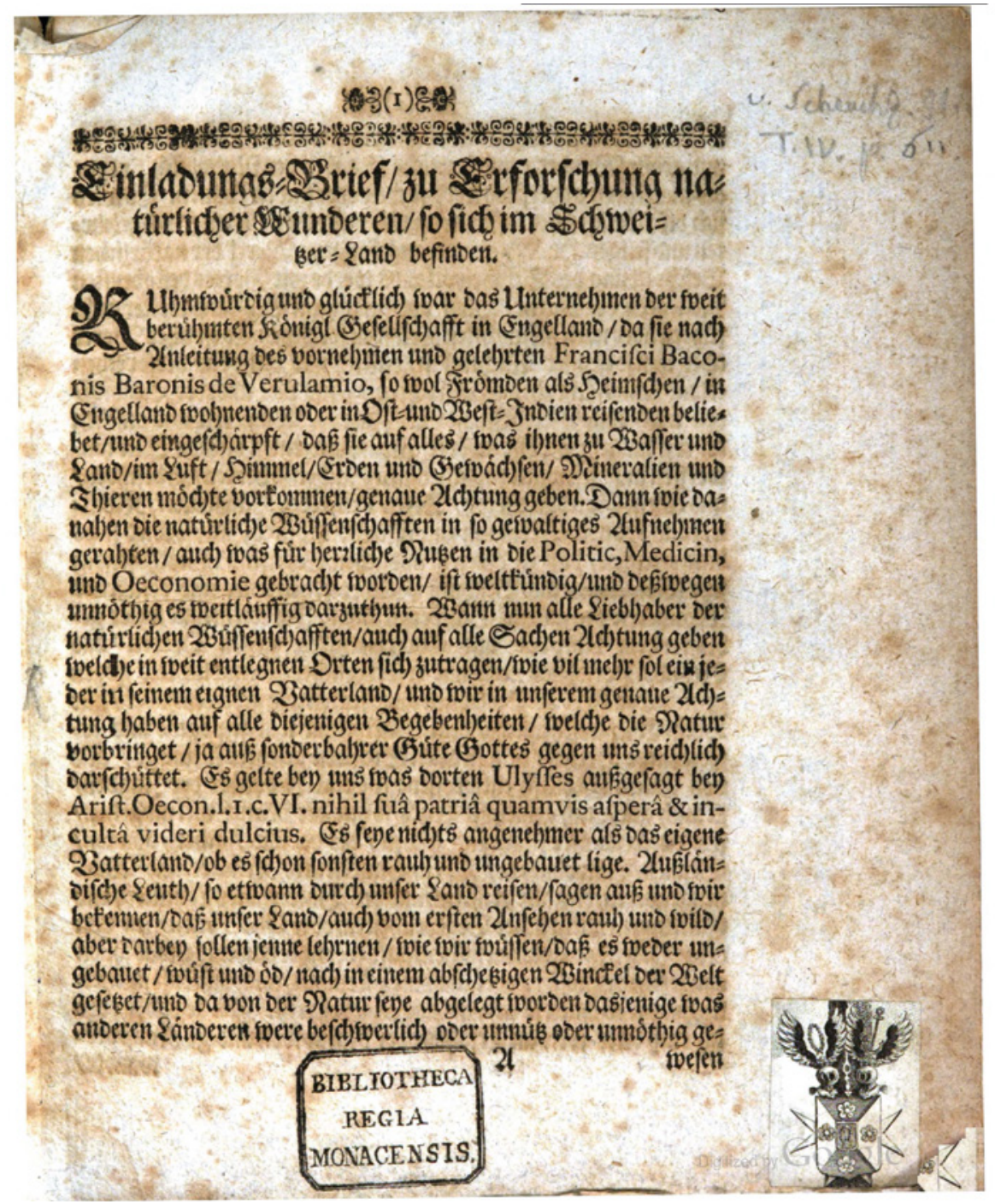

FIGURE 2.1 Johann Jakob Scheuchzer, Einladungs-Brief, zu Erforschung natürlicher Wunderen, so sich im Schweizer-Land befinden, [Zurich], 1699, 1. Bayerische Staatsbibliothek Digital, Signatur: 4 H.nat. 141 b 
a physician and Professor of Physics at Gresham College in London. ${ }^{43}$ Woodward was also the author of a questionnaire entitled Brief Instructions for Making Observations in all parts of the World. ${ }^{44}$

In Scheuchzer's questionnaire, we can find similarities with Boyle's and Woodward's texts. The Swiss scholar repeated Boyle's organization of the queries on "Supraterraneous, Terrestrial, and Subterraneous" topics, and the first groups of questions concerning the coordinates of a place, the quality of air and climate, are similar to Boyle's General heads. Other questions concerning observation of local inhabitants, weather forecast and the height of mountains, their changes and the presence of snow can be interpreted as examples of an intertextuality between Boyle's and Woodward's questionnaires and Scheuchzer's one. However, Scheuchzer adapted the questions to suit the peculiarity of his country and of its most unknown regions, the Alps. About fifteen queries referred to milk and dairy products, which Scheuchzer saw as very typical components of his compatriots' diet. Alps and mountains are mentioned almost thirty-five times in the Einladungsbrief, and fourteen questions concerned snow, glaciers, avalanches, or ice. ${ }^{45}$

Very interestingly, Scheuchzer received several long answers to his questionnaire, especially from pastors of the Reformed Church and from noblemen of an Alpine region, the Free State of the Three Leagues of Grisons (today Canton

43 Since 1704, Scheuchzer had been Fellow of the Royal Society. Woodward became one of the most important correspondents of Scheuchzer in London. The contacts between the two men remained very close from 1701 until 1726, because of Scheuchzer's keen interest in the diluvial theory advocated by the English doctor in his Essay: John Woodward, An Essay Toward a Natural History of the Earth and Terrestrial Bodies, Especially Minerals As Also of the Sea, Rivers, and Springs With an Account of the Universal Deluge And of the Effects That It Had Upon the Earth (London: Printed for Ric. Wilkin, 1695); about Woodward, Scheuchzer and diluvialism: Michael Kempe, Wissenschaft, Theologie, Aufklärung:Johann Jakob Scheuchzer (1672-1733) und die Sintfluttheorie (Epfendorf: bibliotheca academica Verlag, 2003).

44 The text has an appendix on queries about the "Natives of Guinea, Monomotapa, and other less known parts of Africa: of the East, and West Indies: Tartary, Greenland, or any other remote and uncivilized, or Pagan Countries". John Woodward, Brief Instructions for Making Observations, and Collections in Order to the Promotion of Natural History, in All Parts of the World: As Also, for Collecting, Preserving, and Sending over Natural Things (London: Printed for Richard Wilkin, 1696); Victor A. Eyles, "Woodward, John" in Gillispie, Complete Dictionary of Scientific Biography.

45 Boscani Leoni, "Unglaubliche Bergwunder," 37-49: questions no. 1-15 (air, weather), questions no. 97-99 (mountains, their height), questions no. 118-23 (inhabitants). See also: Boyle, "General heads for a natural history of a countrey, great or small, imparted likewise by Mr. Boyle", 186-87 (air, weather), 188 (inhabitants); Woodward, Brief Instructions for making Observations, and Collections in order to the promotion of Natural History, in all parts of the World, 3 (weather), 6 (weather forecast). 
of Grisons). These informants often referred to the Charta invitatoria in their own letters, replying quite articulately, and enclosing sketches of mountain outlines, Alpine plants, minerals, crystals or again transcriptions of accounts about dragons encountered by shepherds, hunters, and valley dwellers in the Alps. Scheuchzer often re-used this information, sometimes mentioning his sources in his works. ${ }^{46}$

The last step in my investigation about the appropriation/adaptation of queries as information-gathering tools takes us to Italy. At the beginning of the 18th century, Scheuchzer was the centre of a scholars network interested in the question of the origin of the Earth and in the interpretation of fossils. In this network we can find scholars like John Woodward, Friedrich Leopold (1651-1722), Louis Bourguet (1678-1742), Karl Nikolaus Lang (1670-1741), Luigi Ferdinando Marsili (1658-1730), and Antonio Vallisneri (1661-1730). Contacts with Luigi Ferdinando Marsili and Antonio Vallisneri was intense, especially over the $1703^{-1705}$ period. ${ }^{47}$ From 1705 onwards, Johann Jakob Scheuchzer's

46 Simona Boscani Leoni, "Centri e periferie. Alcune riflessioni sulla corrispondenza erudita tra Sei e Settecento," Schweizerische Zeitschrift für Geschichte 55, no. 4 (2005); "Queries and Questionnaires: Collecting Local and Popular Knowledge in 17th and 18th Century Europe," in Wissenschaftsgeschichte und Geschichte des Wissens im Dialog - Connecting Science and Knowledge, ed. Kaspar von Greyerz, Silvia Flubacher, and Philipp Senn (Göttingen: V\&R unipress, 2013); "Men of Exchange: Creation and Circulation of Knowledge in the Swiss Republics of Eighteenth Century," in Scholars in Action: The Practice of Knowledge and the Figure of the Savant in the 18th Century, ed. André Holenstein, Hubert Steinke and Martin Stuber, 2 vols. (Leiden: Brill, 2013). Two long answers to Scheuchzer's Einladungsbrief came from the pastor of the reformed church Johann Leonhardi (1651-1725) and from the nobleman Rudolf von Rosenroll (1671-1730), Boscani Leoni, "Unglaubliche Bergwunder," 86-99 (Leonhardi to Scheuchzer, 23 November 1699 [Gregorian calendar 3 December 1699]), 117-23 (Rosenroll to Scheuchzer, 15 February.[1700] [Gregorian calendar 25 February 1700]); online: Boscani Leoni, "Lettres des Grisons": Wissenschaft, Religion und Diplomatie in der Korrespondenz von Johann Jakob Scheuchzer. Eine Edition ausgewählter Schweizer Briefe (1695-1731), hallerNet.org, 2019: https://hallernet.org/edi tion/scheuchzer-korrespondenz; for Leonhardi: https://hallernet.org/edition/scheuchzer -korrespondenz/letter/18055?view=tf\&option1=yes\&option2=yes\&option3=yes\&transl ation=inactive; for Rosenroll: https://hallernet.org/edition/scheuchzer-korrespondenz/ letter/18174?view=tf\&option1=yes\&option2=yes\&option3=yes\&translation=inactive, accessed on 20 April 2021.

47 Marsili sent 62 letters to Zurich in the timespan between 1703 and 1730 and received 55 answers from Scheuchzer; in the period from 1701 to 1728 Scheuchzer wrote 16 letters to Vallisneri and received 9o answers. See: Rudolf Steiger, "Verzeichnis des Wissenschaftlichen Nachlasses von Johann Jakob Scheuchzer," Beiblatt zur Vierteljahresschrift der Naturforschenden Gesellschaft in Zürich 78, no. 21 (1933), 71. On the correspondence between Marsili and Vallisneri, see for example: Marta Cavazza, Settecento inquieto: alle origini dell'Istituto delle Scienze di Bologna (Bologna: Il Mulino, 199o); Dario Generali, Antonio Vallisneri: gli anni della formazione e le prime ricerche (Florence: Olschki, 2007); Francesco 
brother, Johann (1684-1738), acted as secretary and scientific assistant to Marsili, particularly during his journeys through the Swiss Alps, when the latter collected very important information about the structure of mountains. Based on morphological criteria, Marsili classified mountains into three groups: as a whole, as a result of irregular ruins, and as a combination of strata. In the same period, Vallisneri - motivated by a desire to prove his new theories about the origin of springs and mountains - undertook a long explorative journey in the Garfagnana (a mountainous territory between the Apuan Alps and the Apennines) and in 1705 he wrote an account of his journey in his Primi itineris per Montes specimen Physico-Medico. ${ }^{48}$ As we know, the Philosophical Transactions did not publish the text and only several years later, sometime between 1722 and 1726, Vallisneri printed it under the pseudonym of Giovanni Battista Perrucchini in the Supplementi al Giornale de' Letterati d'Italia. In the appendix to this account, there is a list of 26 queries. ${ }^{49}$

Vallisneri's queries focus on questions about springs, mountain strata, mountain configuration, and fossils, which happen to be the main topics of the correspondence with Johann Jakob Scheuchzer. The Italian scholar was not convinced of Woodward's and Scheuchzer's diluvial theory and interpreted mountain strata as a consequence of different inundations. ${ }^{50}$ His and Scheuchzer's questionnaires have many similar questions in common. Without difficulty, we can interpret Vallisneri's queries as an "appropriation" of the genre following Scheuchzer's model. One can find similarities between the two texts in the questions on fossils and springs and on the quality of water (temperature, smell and colour, presence of metals like copper or materials like sulphur). ${ }^{51}$

Luzzini, Il miracolo inutile: Antonio Vallisneri e le scienze della terra in Europa tra XVII e XVIII secolo (Florence: Olschki, 2013).

48 Francesco Luzzini, ed. Theory, Practice, and Nature In-between. Antonio Vallisneri's Primi Itineris Specimen (Berlin: Edition Open Access/Max Planck Institute for the History of Science, 2018). http://www.edition-open-sources.org/sources/9/, accessed on 2o April 2021. See also the contribution of Francesco Luzzini in this volume.

49 Antonio Vallisneri, "Estratto d'alcune Notizie intorno alla Provincia della Garfagnana, cavate dal primo Viaggio Montano del Sig. Antonio Vallisnieri, [...] dal Sig. Dottore Giovanbatista Perrucchini," Supplementi al Giornale de' Letterati d'Italia II (1722, Articolo viI); Vallisneri, "Continuazione dell'estratto d'alcune Notizie intorno alla Garfagnana cavate dal primo Viaggio Montano del Sig. Antonio Vallisneri," Supplemento al Giornale de' Letterati d'Italia III (1726, Articolo VIII); for the questionnaire: 1726, 404-19. See also: Luzzini, Il miracolo inutile, 88-94.

$5^{\circ}$ See the manuscripts of the letters in the Zentralbibliothek Zürich, Ms. H 312, H 305.

$5^{1}$ Antonio Vallisneri, Primi Itineris per Montes Specimen Physico-Medicum. 1705, 52-53 of the manuscript; edition: Luzzini, Theory, Practice and Nature In-between. Antonio Vallisneri's Primi Itineris Specimen, 345-46, 124-25 and English translation, 198-99; online: http:// www.edition-open-sources.org/sources/9/, accessed on 20 April 2021; the printed version 
One can also find similarities in the queries on insects and plants, especially on mountain vegetation. ${ }^{52}$ There is also a most remarkable similarity in the Scheuchzer's and Vallisneri's inquiries on the nature and customs of the local/ native inhabitants, on their body size and habits, on the techniques of preparation of dairy products by peasants, and on the measurement of the height of mountains with barometer and thermometer. ${ }^{53}$ Mountains, hydrography as well fossils, mountains plants, animals and local economy (milk, cheese) figured very prominently in both questionnaires.

\section{4}

\section{Conclusion}

As we have seen, questionnaires played an important role in the process of state building in the early modern age, especially in the Spanish and British colonial empire building. They are also a very efficient instrument for the empirical investigation of civil and natural history. We have also stressed how important Spanish America was as a place for establishing new forms of empirical practices during the 16 th century. One can notice a similar process in Britain, where the same types of information-gathering tools were "appropriated" and adapted to local needs. Here, one may observe the specialization of queries in two different types: queries for travellers that aimed to conduct and organize their scientific observations and questionnaires to obtain information about antiquities and natural history of a local territory. The questionnaires of Robert Plot for Oxfordshire and Staffordshire illustrate it very well. Scholars in Switzerland and in Italy, two countries on the sidelines of the colonial expansion, applied this tool as a "local" research instrument reorienting it to discovering less-well-known European territories, like the Alps, the Apuan Alps and the Apennines Mountains. Through Scheuchzer's and Vallisneri's

in: Vallisneri, “Continuazione dell'estratto d'alcune notizie intorno alla Garfagnana cavate dal primo Viaggio Montano del Sig. Antonio Vallisneri," 404, 406-09, Scheuchzer questions no. 71, 73, 170, 174 (questions no. 168 and 172 in the Latin questionnaire). Boscani Leoni, "Unglaubliche Bergwunder", 41-42, 47-48.

52 Vallisneri, "Continuazione dell'estratto d'alcune Notizie intorno alla Garfagnana cavate dal primo Viaggio Montano del Sig. Antonio Vallisneri," 409-10, 404; Scheuchzer, questions 162 (Latin no. 160) and 124-32; Boscani Leoni, "Unglaubliche Bergwunder", 44-47.

53 Vallisneri, "Continuazione dell'estratto d'alcune notizie intorno alla Garfagnana cavate dal primo Viaggio Montano del Sig. Antonio Vallisneri," 413-17; Scheuchzer, questions no. 97, 117-23, 175-89 (Latin questions no. 173-86). Scheuchzer did barometrical experiments and regular measurements of the temperature of the air during his journeys through the Swiss Alps. 
information-gathering campaign, European peripheral mountain regions gradually became centres for investigating the origin of the Earth and studying natural history.

In addition, questionnaires are an extremely interesting tool if we want to follow the development of empiricism in the history of knowledge and in the modern history of science. They were an excellent device for improving knowledge of a territory, of its resources; and, as colonial history has shown, for controlling and exploiting territories and people. During the Enlightenment, they became again very valuable and widespread information-gathering tools in the form of economical, demographical, and agricultural surveys implemented by economic societies to improve "patriotic reforms" of the territories. ${ }^{54}$

For this reason, questionnaires force us to reflect on the close relationship between information and power, a very important issue not only for the past, but also for our present and future.

\section{Acknowledgements}

This contribution is based on research funded by the Swiss National Science Foundation and carried out in the context of the projects "Kulturen der Naturforschung" (Cultures of Natural History), Projects-Nr. 144731 and 176978, at the University of Bern (2014 - ongoing).

I would also like to thank the Royal Society Archives for providing me with copies of the documents used for this research.

\section{Bibliography}

\section{Manuscripts}

Royal Society, Archives of the Royal Society, London, Classified papers (Cl.P.): Vol. XIX "Inquiries and Answers, December 24, 1662-May 25, 1692."

Vol. XIX/19/93: "Questions to be asked to the most ingenious of each County in my Travels through England" by R[obert] P[lot].

54 For example, see the surveys of the Economic society of Bern (Oekonomische Gesellschaft Bern): Gerrendina Gerber-Visser, Die Ressourcen des Landes: Der ökonomisch-patriotische Blick in den Topographischen Beschreibungen der Oekonomischen Gesellschaft Bern (17591855) (Baden: hier + jetzt, 2012). 
Vol. XIX/19/94: "Enquiries to be propounded to the most Ingenious of each County in my Travels through England and Wales, in order to their History of Nature and Arts" by $\mathrm{R}$ [obert] P[lot].

\section{Printed Sources}

“[An Account of Four Books]." Philosophical Transactions 13, no. 143-154 (1683): 259-74. Bacon, Francis. New Atlantis: A Work Unfinished. London: Printed by Tho. Newcomb, $165^{8 .}$

Bacon, Francis. The Works of Francis Bacon, edited by James Spedding, Robert Leslie Ellis and Douglas Denon Heath. 14 vols. London: Longman [etc.], 1857-1874.

Bacon, Francis. Nova Atlantis. Library of Latin Texts. Turnhout: Brepols Publishers, 2014.

Bernardino de Sahagún, Florentine Codex: General History of the Things of New Spain, translated from the Aztec into English, with notes and ill. by Arthur James Outram Anderson, and Charles E. Dibble, 1. paperback ed., Monographs of the School of American Research 14. Salt Lake City: University of Utah Press, 2012.

Birch, Thomas. The History of the Royal Society of London for Improving of Natural Knowledge: From Its First Rise, in Which the Most Considerable of Those Papers Communicated to the Society, Which Have Hitherto Not Been Published, are Inferted in Their Proper Order, as a Supplement to the Philosophical Transactions [Facsimile]. Bruxelles: Culture et civilisation, 1967-1968, 4 vols. (original edition: London,

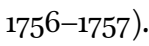

Boate, Arnold. "An Interrogatory Relating more particularly to the Husbandry and Natural History of Ireland." In Samuel Hartlib His Legacie, Or, an Enlargement of the Discourse of Husbandry Used in Brabant \& Flaunders: Wherein Are Bequeathed to the Common-Wealth of England More Outlandish and Domestick Experiments and Secrets in Reference to Universall Husbandry, edited by Samuel Hartlib, Cressy Dymock, Robert Child, and Richard Weston, The 2nd ed., augmented with an appendix (London: Printed by R. \& W. Leybourn for Richard Wodenothe, 1652), Appendix, without pagination.

Boate, Gerard. Irelands Naturall History: Being a True and Ample Description of Its Situation, Greatness, Shape, and Nature, of Its Hills, Woods, Heaths, Bogs [...] With Its Heads or Promontories, Harbours, Roades, and Bayes [...] Of Its Metalls, Mineralls [...] Turf [...] And Lastly, of the Nature and Temperature of Its Air and Season, and What Diseases It Is Free From, or Subject Unto. London: For John Wright, $165^{2}$.

Boscani Leoni, Simona, ed. "Lettres des Grisons": Wissenschaft, Religion und Diplomatie in der Korrespondenz von Johann Jakob Scheuchzer. Eine Edition ausgewählter Schweizer Briefe (1695-1731), https://hallernet.org/edition/scheuchzer -korrespondenz (accessed on 20 April 2021). 
Boscani Leoni, Simona, ed. "Unglaubliche Bergwunder": Johann Jakob Scheuchzer und Graubünden. Ausgewählte Briefe 1699-1707. Cultura alpina Band 9. Chur: Verlag Bündner Monatsblatt, 2019.

Boyle, Robert. "General Heads for a Natural History of a Countrey, Great or Small, Imparted Likewise by Mr. Boyle." Philosophical Transactions 1, no. 11 (1665): 186-89.

Boyle, Robert. "Other Inquiries Concerning the Sea." Philosophical Transactions 1, no. 18 (1665): 315-16.

Boyle, Robert. General Heads for the Natural History of a Country Great or Small: Drawn Out for the Use of Travellers and Navigators / Imparted by [...] Robert Boyle [...]; to Which Is Added, Other Directions for Navigators, Etc. With Particular Observations of the Most Noted Countries in the World; by Another Hand. London: Printed for John Taylor [...] and S. Hedford, 1692.

Boyle, Robert. The Works of Robert Boyle. Edited by Hunter, Michael Cyril William and Edward B. Davis. London: Pickering \& Chatto, 1999.

Collini, Silvia, and Antonella Vannoni, eds. Les instructions scientifiques pour les voyageurs (XVII ${ }^{e}-X I X^{e}$ siècle). Paris: L'Harmattan, 2005.

Hall, Alfred Rupert, and Marie Boas Hall, eds. The Correspondence of Henry Oldenburg. 13 vols. Philadelphia, Pa.: Taylor \& Francis, 1965-1986.

"Inquiries for Suratte, and Other Parts of the East-Indies; Inquiries for Persia. Inquiries for Virginia and the Bermudas. For Guaiana and Brasil." Philosophical Transactions 2, no. 23 (1666): $415^{-22 .}$

"Inquiries of Directions for the Ant-Iles, or Caribe-Islands." Philosophical Transactions 3 , no. 33 (1668): 634-39.

Plot, Robert. The Natural History of Oxford-Shire: Being an Essay Toward the Natural History of England. Oxford: At Mr. S. Millers, 1677.

Plot, Robert. The Natural History of Stafford-Shire. Oxford: Printed at the Theater, 1686.

Rooke, Laurence. "Directions for Sea-Men, Bound for Far Voyages." Philosophical Transactions 1, no. 8 (1665-1666): 140-43.

Solano, Francisco de, ed. Cuestionarios para la formación de las Relaciones Geográficas de Indias: siglos XVI/XIX. V centenario del descubrimiento de América 25. Madrid: Consejo Superior de Investigaciones Científicas, 1988.

Scheuchzer, Johann Jakob. Einladungs-Brief, zu Erforschung natürlicher Wunderen, so sich im Schweizer-Land Befinden. Zurich: [D. Gessner], 1699. In Boscani Leoni, "Unglaubliche Bergwunder":Johann Jakob Scheuchzer und Graubünden. Ausgewählte Briefe 1699-1707, 33-49.

Scheuchzer, Johann Jakob. Charta invitatoria, quaestionibus, quae historiam Helvetiae naturalem concernunt, praefixa. Tiguri: [D. Gessner], 1699 .

Scheuchzer, Johann Jakob. Bibliotheca scriptorum historiae naturalis omnium Terrae Regionum inservientium; historiae naturalis Helvetiae Prodromus; accessit Celeberrimi 
Viri Jacobi Le Long, Bibliothecarii Oratoriani de Scriptoribus historiae naturalis Galliae; collegit Johann Jakob Scheuchzer, Med. D. Math. Prof. Societ. Leopoldino-Carolinae, Regiae Angl. \& Boruss. Tiguri: Typis Henrici Bodmeri, 1716.

Scheuchzer, Johann Jakob, and Johann Rudolf Lavater. Historiae helveticae naturalis prolegomena publicae Eruditorum Syzētēsei subiecta praeside I. Iacobo Scheuchzero [...], Respondente Iohanne Rodolfo Lavatero [...] In Auditorio Aestivo H.L.Q.S. Die Septembr. Tiguri: Gessner, 1700.

Luzzini, Francesco, ed. Theory, Practice, and Nature In-between. Antonio Vallisneri's Primi Itineris Specimen. Berlin: Edition Open Access/Max Planck Institute for the History of Science, 2018. http://www.edition-open-sources.org/sources/9/; accessed on 20 April 2021.

Vallisneri, Antonio. "Estratto d'alcune notizie intorno alla Provincia della Garfagnana, cavate dal primo Viaggio Montano del Sig. Antonio Vallisneri, [...] dal Sig. Dottore Giovanbatista Perrucchini, e da lui indirizzato in una lettera al Sig. Lodovico da Riva." Supplementi al Giornale de' Letterati d'Italia II (1722, Articolo VII): 270-312.

Vallisneri, Antonio. "Continuazione dell'estratto d'alcune notizie intorno alla Garfagnana cavate dal primo Viaggio Montano del Sig. Antonio Vallisneri." Supplemento al Giornale de' Letterati d'Italia III (1726, Articolo VIII): 376-428.

Wagner, Johann Jacob. Historia naturalis Helvetiae curiosa. Tiguri: Joh. Henrici Lindinneri, 168o.

Woodward, John. An Essay Toward a Natural History of the Earth and Terrestrial Bodies, Especially Minerals As Also of the Sea, Rivers, and Springs With an Account of the Universal Deluge And of the Effects That It Had Upon the Earth. Early. London: Printed for Richard Wilkin, 1695.

Woodward, John. Brief Instructions for Making Observations, and Collections in Order to the Promotion of Natural History, in All Parts of the World: As Also, for Collecting, Preserving, and Sending over Natural Things. London: Printed for Richard Wilkin, 1696.

\section{Literature}

Álvarez Peláez, Raquel. "El Cuestionario de 1577. La 'Instruccion y memoria de las relaciones que se han de hacer para la descripcion de las Indias' de 1577." In Solano, Cuestionarios para la formación de las relaciones geográficas de Indias, XCIII-CVI.

Álvarez Peláez, Raquel. La conquista de la naturaleza americana. Cuadernos Galileo de historia de la ciencia 14. Madrid: Consejo Superior de Investigaciones Científicas, 1993.

Barrera, Antonio. "Empire and Knowledge: Reporting from the New World." Colonial Latin American Review 15, no. 1 (June, 2006): 39-54. 
Barrera-Osorio, Antonio. Experiencing Nature: The Spanish American Empire and the Early Scientific Revolution. 1st ed. Austin: University of Texas Press, 2006.

Barrera-Osorio, Antonio. "Nature and Experience in the New World: Spain and England in the Making of the New Science." In Más allá de la Leyenda Negra: España y la revolución cientifica = Beyond the Black Legend; Spain and the Scientific Revolution, edited by Víctor Navarro Brotons and William Eamon, 121-35. Valencia: Universitat de Valencia, 2007.

Barrera-Osorio, Antonio. "Empiricism in the Spanish Atlantic World." In Science and Empire in the Atlantic World, edited by James Delbourgo and Nicholas Dew, 177-2O2. New York: Routledge, 2008.

Barrera-Osorio, Antonio. "Knowledge and Empiricism in the Sixteenth-Century Spanish Atlantic World." In Science in the Spanish and Portuguese Empires, 1500180o, edited by Daniela Bleichmar, Paula De Vos, Kristin Huffine, and Kevin Sheehan, 219-32. Stanford: Stanford University Press, 2009.

Benavides, Carmen Millán de. Epítome de la Conquista del Nuevo Reino de Granada: la cosmogonía española del siglo XVI y el conocimiento por cuestionario. Bogotá: Pontificia Universidad Javeriana, Instituto de Estudios Sociales y Culturales Pensar, 2001.

Blanckaert, Claude, ed. Le terrain des sciences humaines: instructions et enquêtes $\left(X V I I I^{e}-X X^{e}\right.$ siècle). Histoire des sciences humaines. Paris: L'Harmattan, 1996.

Bordat, Josef. "Bacons Atlantis-Mythos und das Selbstverständnis der modernen Wissenschaft." In Mythos - Helden - Symbole Legitimation, Selbst- und Fremdwahrnehmung in der Geschichte der Naturwissenschaften der Medizin und der Technik, edited by Siegfried Bodenmann and Susan Splinter, 121-30. Munich: Martin Meidenbauer, 2009.

Boscani Leoni, Simona. "Centri e periferie. Alcune riflessioni sulla corrispondenza erudita tra Sei e Settecento." Schweizerische Zeitschrift für Geschichte 55, no. 4 (2005): 441-47.

Boscani Leoni, Simona. "Men of Exchange: Creation and Circulation of Knowledge in the Swiss Republics of Eighteenth-Century." In Scholars in Action: The Practice of Knowledge and the Figure of the Savant in the 18th Century, edited by André Holenstein, Hubert Steinke, and Martin Stuber. 2 vols., 507-33. Leiden: Brill, 2013.

Boscani Leoni, Simona. "Queries and Questionnaires: Collecting Local and Popular Knowledge in 17th and 18th Century Europe." In Wissenschaftsgeschichte und Geschichte des Wissens im Dialog - Connecting Science and Knowledge, edited by Kaspar von Greyerz, Silvia Flubacher, and Philipp Senn, 187-207. Göttingen: V\&R unipress, 2013.

Bossi, Maurizio, and Claudio Greppi, eds. Viaggi e scienza: le istruzioni scientifiche per i viaggiatori nei secoli XVII-XIX. Gabinetto scientifico letterario G.P. Vieusseux 13. Florence: Olschki, 2005. 
Boumediene, Samir. La colonisation du savoir une histoire des plantes médicinales du "Nouveau Monde" (1492-1750). Vaulx-en-Velin: Les éditions des mondes à faire, 2016.

Bourguet, Marie-Noëlle. "Voyages lointains et mesure du monde: la projection du regard européen sur le monde (vers 1500-vers 1800)." In L'Europe des sciences et des techniques $X V^{e}-X V I I I^{e}$ siècle: $u n$ dialogue des savoirs, edited by Liliane Hilaire-Pérez, Fabien Simon, and Marie Thébaud-Sorger, 193-201. Rennes: Presses universitaires de Rennes, 2016.

Brendecke, Arndt. Imperium und Empirie: Funktionen des Wissens in der spanischen Kolonialherrschaft. Cologne: Böhlau, 2009.

Brendecke, Arndt. "Informing the Council. Central Institutions and Local Knowledge in the Spanish Empire." In Empowering Interactions: Political Cultures and the Emergence of the State in Europe 1300-1900, edited by Willem Pieter Blockmans, André Holenstein, and Jon Mathieu, 235-52. Farnham: Ashgate, 2009.

Brockway, Lucile H. Science and Colonial Expansion: The Role of the British Royal Botanic Gardens. 2nd ed. (1st ed. 1979). New Haven, London: Yale University Press, 2002.

Burke, Peter. The Historical Anthropology of Early Modern Italy: Essays on Perception and Communication. Cambridge, New York: Cambridge University Press, 1987.

Burke, Peter. A Social History of Knowledge: From Gutenberg to Diderot. Cambridge: Blackwell Publishers, 2000.

Bustamante García, Jesús. "Francisco Hernández, Plinio del Nuevo Mundo: tradición clásica, teoría nominal y sistema terminológico indígena en una obra renacentista." In Entre dos mundos. Fronteras culturales y agentes mediadores, edited by Berta Ares Queija and Serge Gruzinski, 243-68. Sevilla: Escuela de Estudios HispanoAmericanos, 1997.

Bustamante García, Jesús. “La empresa naturalista de Felipe II y la primera expedición cientifica en suelo americano. La creación del modelo expedicionario renacentista." In Felipe II (1527-1598): Europa y la monarquía católica. Vol. 4, edited by José Martinez Millán, 39-59. Madrid: Editorial Parteluz, 1998.

Cañizares-Esguerra, Jorge. "Spanish America: From Baroque to Modern Colonial Science." In Porter, The Cambridge History of Science: Eighteenth-Century Science, 718-40.

Cañizares-Esguerra, Jorge. "Iberian Science in the Renaissance: Ignored How Much Longer?" Perspectives on Science 12, no. 1 (2004): 86-124.

Cañizares-Esguerra, Jorge. Nature, Empire, and Nation: Explorations of the History of Science in the Iberian World. Stanford, California: Stanford University Press, 2006.

Carey, Daniel. "Compiling Nature's History: Travellers and Travel Narratives in the Early Royal Society." Annals of Science 54, no. 3 (1997): 269-92.

Carey, Daniel. "Inquiries, Heads, and Directions: Orienting Early Modern Travel." In Travel Narratives, the New Science and Literary Discourse: 1569-1750, edited by Judy A. Hayden, 25-52. Farnham: Ashgate, 2012. 
Cavazza, Marta. Settecento inquieto: alle origini dell'Istituto delle Scienze di Bologna. Bologna: Il Mulino, 1990.

Chakrabarty, Dipesh. Provincializing Europe: Postcolonial Thought and Historical Difference. Princeton studies in culture, power, history. Princeton: Princeton University Press, 2000.

Clericuzio, Antonio. "Le accademie scientifiche del Seicento." In Il contributo italiano alla storia del pensiero. Scienze, edited by Antonio Clericuzio and Saverio Ricci, 38-45. Roma: Istituto della Enciclopedia Italiana fondata da Giovanni Treccani, 2013 .

Cline, Howard F. “The Relaciones Geográficas of the Spanish Indies, 1577-8." Hispanic American Historical Review 44 (1964): 341-74.

Cline, Howard F. "The Relaciones Geográficas of Spain, New Spain, and the Spanish Indies: An Annotated Bibliography." In Handbook of Middle American Indians, edited by Howard F. Cline and Robert Wauchope, 370-95. Austin: University of Texas Press, 1972.

Cohen, Ierome Bernard, ed. Puritanism and the Rise of Modern Science: The Merton Thesis. New Brunswick: Rutgers University Press, 199 o.

Cooper, Alix. Inventing the Indigenous: Local Knowledge and Natural History in Early Modern Europe. Cambridge, London: Cambridge University Press, 2007.

Cooper, Alix. "Fragen ohne Antworten: Die Suche nach lokalen Informationen in der frühen Aufklärung." In Vor Google: Eine Mediengeschichte der Suchmaschine im analogen Zeitalter, edited by Thomas Brandstetter, 73-83. Kultur- und Medientheorie. Bielefeld: transcript, 2012.

Davis, Edward B., Winship Michael P. "Early Modern Protestantism." In Science and Religion: A Historical Introduction, edited by Gary B. Ferngren, 117-29. Baltimore: Johns Hopkins University Press, 2002.

Eyles, Victor Ambrose. “Woodward, John." In Gillispie, Complete Dictionary of Scientific Biography, vol. 14, 500-03.

Fan, Fa-ti. "The Global Turn in the History of Science." East Asian Science, Technology and Society: An International Journal 6 (2012): 249-58.

Fox, Adam. "Printed Questionnaires, Research Networks, and the Discovery of the British Isles, 1650-18oo." The Historical Journal 53, no. 3 (2010): 593-621.

Gavroglu, Kostas, Manolis Patiniotis, Faidra Papanelopoulou, Ana Simões, Ana Carneiro, Maria Paula Diogo, José Ramón Bertomeu Sánchez, Antonio García Belmar, and Agustí Nieto-Galan. "Science and Technology in the European Periphery: Some Historiographical Reflections." History of Science 46, no. 2 (2008): 153-75.

Generali, Dario. Antonio Vallisneri: gli anni della formazione e le prime ricerche. Biblioteca dell'edizione nazionale delle opere di Antonio Vallisneri 2. Florence: Olschki, 2007. 
Gerber-Visser, Gerrendina. Die Ressourcen des Landes: Der ökonomisch-patriotische Blick in den Topographischen Beschreibungen der Oekonomischen Gesellschaft Bern (1759-1855). Archiv des Historischen Vereins des Kantons Bern 89. Baden: hier + jetzt, 2012.

Gillispie, Charles Coulston, ed. Complete Dictionary of Scientific Biography. 18 vols. Detroit: Charles Scribner's Sons, 2008.

Guerrini, Luigi. "Piante e animali del Nuovo Mondo. Federico Cesi e il Tesoro messicano." In Le scienze, edited by Antonio Clericuzio and Germana Ernst. 12 vols., 197213. Il rinascimento italiano e l'Europa 5. Treviso: Colla, 2008.

Hunter, Michael. "Robert Boyle's 'Heads' and 'Inquiries'. Robert Boyle Project, Occasional Papers no. 1 (2005). URL: http://www.bbk.ac.uk/boyle, accessed on 20 April 2021.

Hunter, Michael. "Robert Boyle and the Early Royal Society: A Reciprocal Exchange in the Making of Baconian Science." The British Journal for the History of Science, 40 (2007): 1-23.

Iliffe, Rob. "Science and Voyages of Discovery." In Porter, The Cambridge History of Science: Eighteenth-Century Science, 618-46.

Keller, A. G. "Plot, Robert." In Gillispie, Complete Dictionary of Scientific Biography, vol. 11, 40-41.

Kempe, Michael. Wissenschaft, Theologie, Aufklärung:Johann Jakob Scheuchzer (16721733) und die Sintfluttheorie. Frühneuzeit-Forschungen 10, edited by Peter Blickle, Richard van Dülmen, Heinz Schilling, and Winfried Schulze. Epfendorf: bibliotheca academica Verlag, 2003.

León Portilla, Miguel. Bernardino de Sahagún. Protagonistas de América. Madrid: Historia $16,1987$.

Livingstone, David N. Putting Science in Its Place: Geographies of Scientific Knowledge. Chicago, London: The University of Chicago Press, 2003.

López Austin, Alfredo. "Estudio acerca del método de investigación de fray Bernardino de Sahagún." In La investigación social de campo en México, edited by Jorge Martínez Ríos, 9-56. México: Universidad Nacional Autónoma, 1976.

López Austin, Alfredo. "Estudio acerca del método de investigación de fray Bernardino de Sahagún." Estudios de Cultura Náhuatl 42 (2011): 353-40o.

López Piñero, José M. "Sahagún, Bernardino de." In Diccionario Histórico de la Ciencia Moderna en España. Vol. 2, edited by José M. López Piñero, 281-82. Historia, ciencia, sociedad 181. Barcelona: Ed. Península, 1983.

Luzzini, Francesco. Il miracolo inutile: Antonio Vallisneri e le scienze della terra in Europa tra XVII e XVIII secolo. Biblioteca dell'edizione nazionale delle opere di Antonio Vallisneri 9. Florence: Olschki, 2013.

Mazzone, Umberto and Angelo Turchini, eds. Le visite pastorali: analisi di una fonte. Annali dell'Istituto storico italo-germanico. Quaderno. Bologna: Il Mulino, 1991. 
Mundy, Barbara E. The Mapping of New Spain: Indigenous Cartography and the Maps of the Relaciones Geográficas. Chicago, London: The University of Chicago Press, 1996. Ogilvie, Brian W. The Science of Describing. Natural History in Renaissance Europe. Chicago, London: The University of Chicago Press, 2006.

Ponce Leiva, Pilar. "Las Ordenanzas sobre Descripciones (1573). Su aplicación en la Real Audiencia de Quito." In Solano, Cuestionarios para la formación de las relaciones geográficas de Indias, LXXIX-XCI.

Porter, Roy, ed. The Cambridge History of Science: Eighteenth-Century Science 4. Cambridge, New York: Cambridge University Press, 2003.

Raj, Kapil. "Relocations." In Science and Technology Studies: Critical Concepts in the Social Sciences. Vol. 4, edited by Michael Lynch, 3-11. London: Routledge, 2012.

Raj, Kapil. “Quand l'Amérique a inventé la science européenne." In Europa: une autre histoire, edited by Jakob Vogel, Thomas Serrier, and Etienne François, 1089-1102. Paris: Les Arènes, 2017.

Raj, Kapil. "Thinking Without the Scientific Revolution: Global Interactions and the Construction of Knowledge." Journal of Early Modern History 21 (2017): 1-14.

Roberts, Lissa. "Situating Science in Global History: Local Exchanges and Networks of Circulation." Itinerario 33, no. 1 (2009): 9-30.

Rubiés, Joan-Pau. "Instructions for Travellers: Teaching the Eye to See." History and Anthropology 9, no. 2-3 (1996): 139-9o.

Schiebinger, Londa, and Claudia Swan, eds. Colonial Botany: Science, Commerce, and Politics in the Early Modern World. Philadelphia: University of Pennsylvania Press, 2005 .

Shapin, Steven. "The House of Experiment in Seventeenth-Century England." Isis 79, (1988): 373-404.

Shapin, Steven. A Social History of Truth: Civility and Science in Seventeenth-Century England. Chicago, London: The University of Chicago Press, 1994.

Shapiro, Barbara J. "History and Natural History in Sixteenth and Seventeenth-Century England: An Essay on the Relationship Between Humanism and Science." In English Scientific Virtuosi in the 16th and 17th Centuries: Papers Read at a Clark Library Seminar, 5 February 1977, edited by Barbara J. Shapiro and Robert G. Frank, 3-55. Los Angeles: University of California, William Andrews Clark Memorial Library, 1979.

Shapiro, Barbara J. A Culture of Fact: England, 1550-1720. Ithaca, London: Cornell University Press, 2000.

Sigrist, René, Eric Widmer Eric, and Wladimir Berelowitsch. "Les lieux des sciences dans l'Europe moderne." In Lieux d'Europe: mythes et limites, edited by Stella Ghervas and François Rosset, 45-64. Paris: Ed. de la Maison des sciences de l'homme, 2008.

Slack, Paul. "Government and Information in Seventeenth-Century England." Past and Present 184 (2004): 33-68. 
Stagl, Justin. "Vom Dialog zum Fragebogen: Miszellen zur Geschichte der Umfrage." Kölner Zeitschrift für Soziologie und Sozialpsychologie 31 (1979): 611-38.

Steiger, Rudolf. "Verzeichnis des Wissenschaftlichen Nachlasses von Johann Jakob Scheuchzer." Beiblatt zur Vierteljahresschrift der Naturforschenden Gesellschaft in Zürich 78, no. 21 (1933): 1-75.

Turner, A. J. "Plot, Robert (Bap. 1640, D. 1696), Published Online: 23 September 2004." In The Oxford Dictionary of National Biography. Edited by H. C. G. Matthew and B. Harrison. Oxford: Oxford University Press, 2004. https://doi.org/10.1093/ref :odnb/22385, accessed on 23 September 2019.

Vicente Castro, Florencio. Bernardino de Sahagún primer antropólogo en Nueva España, (siglo XVI). Acta Salmanticensia Filosofía y letras, edited by José-Luis Rodríguez Molinero. Salamanca: Ed. Universidad de Salamanca, Institucíon "Fray Bernardino de Sahagún", Excma. Diputación provincial de León, 1986.

Webster, Charles. The Great Instauration: Science, Medicine and Reform, 1626-1660. 2nd ed., 1st ed. 1975. Studies in the History of Medicine. Oxford: Peter Lang, 2002.

Withers, Charles W. J. Geography, Science, and National Identity: Scotland Since 1520. Cambridge Studies in Historical Geography 33. Cambridge, New York: Cambridge University Press, 2001.

Withers, Charles W. J. Placing the Enlightenment: Thinking Geographically About the Age of Reason. Chicago, London: The University of Chicago Press, 2007.

Yale, Elisabeth. "Making Lists: Social and Material Technologies in the Making of Seventeenth-Century British Natural History." In Ways of Making and Knowing: The Material Culture of Empirical Knowledge, edited by Pamela H. Smith, Amy R. W. Meyers, and Harold J. Cook, 280-301. Ann Arbor: University of Michigan Press, 2014 . 